Check for updates

Cite this: RSC Adv., 2019, 9, 19690

Received 21st March 2019

Accepted 22nd May 2019

DOI: $10.1039 / c 9 r a 02180 a$

rsc.li/rsc-advances

\section{Sequential therapy for pancreatic cancer by losartan- and gemcitabine-loaded magnetic mesoporous spheres $\uparrow$}

\author{
Yanjun Li, ${ }^{a}$ Yuxia Tang, ${ }^{* a}$ Sui Chen, ${ }^{a}$ Ying Liu, ${ }^{a}$ Shouju Wang, ${ }^{\text {ab }}$ Ying Tian, ${ }^{a}$ \\ Chunyan Wang, ${ }^{a}$ Zhaogang Teng (D) *ab and Guangming Lu (D) *ab
}

\begin{abstract}
Sequential therapy has attracted increasing attention for cancer treatment, in which multiple drugs can be used to enhance the therapeutic efficacy. In this work, sequential therapy is demonstrated using amino functionalized $\mathrm{Fe}_{3} \mathrm{O}_{4}$ embedded periodic mesoporous organosilica spheres $\left(\mathrm{Fe}_{3} \mathrm{O}_{4} \mathrm{QPMO}-\mathrm{NH}_{2}\right)$ and $\mathrm{Fe}_{3} \mathrm{O}_{4} \mathrm{QPMO}$ as drug carriers. Losartan can inhibit type I collagen and hyaluronic acid of the pancreatic cancer matrix, which is safe and inexpensive, and does not increase the risk of tumor metastasis. First, losartan is loaded in the $\mathrm{Fe}_{3} \mathrm{O}_{4} \mathrm{aPMO}-\mathrm{NH}_{2}\left(\mathrm{Fe}_{3} \mathrm{O}_{4} \mathrm{QPMO}-\mathrm{NH}_{2}\right.$-Los) to treat pancreatic cancer. Immunohistochemistry staining of tumor slices after treatment with $\mathrm{Fe}_{3} \mathrm{O}_{4}\left(\mathrm{aPMO}-\mathrm{NH}_{2}\right.$-Los confirms that collagen and hyaluronan acid are significantly reduced. The major solid components in the extracellular matrix of the tumor are reduced, which facilitates the penetration of nanodrugs into the tumor site. Afterward, gemcitabine loaded $\mathrm{Fe}_{3} \mathrm{O}_{4}(\mathrm{aPMO}$ $\left(\mathrm{Fe}_{3} \mathrm{O}_{4} \mathrm{OPMO}-\mathrm{Gem}\right)$ is sequentially delivered to treat pancreatic cancer, which shows strong killing ability for the pancreatic cancer cells. Comparing with a saline group, the tumor volume treated with $\mathrm{Fe}_{3} \mathrm{O}_{4} \mathrm{QPMO}$ $\mathrm{NH}_{2}$-Los, $\mathrm{Fe}_{3} \mathrm{O}_{4} \mathrm{QPMO}-\mathrm{Gem}$, and $\mathrm{Fe}_{3} \mathrm{O}_{4} \mathrm{QPMO}-\mathrm{NH}_{2}$-Los $+\mathrm{Fe}_{3} \mathrm{O}_{4} \mathrm{aPMO}-\mathrm{Gem}$ decreases to 92.6\%, 60.7\%, and $28.6 \%$, respectively, suggesting that the sequential therapy significantly inhibits pancreatic tumor growth compared to the mono-therapy strategy. Taken together, this study provides a promising approach for nanomaterials-based sequential therapy for pancreatic cancer treatment.
\end{abstract}

\section{Introduction}

Nanodrugs have attracted much attention for tumor treatment because they effectively improve drug stability, prolong drug circulation, enhance therapeutic efficacy, and reduce the side effects to normal tissues. ${ }^{1-3}$ However, previously reported nanocarriers generally deliver one drug or multiple drugs simultaneously. In contrast, sequential therapy can improve therapeutic efficacy, in which multiple drugs can be used to improve the therapeutic efficacy. ${ }^{4-6}$ In addition, sequential therapy can reduce the side effects by administering drugs separately with a certain sequence and course. ${ }^{7,8}$ Considering the advantages of nanodrugs and sequential therapy, it is highly desirable to develop a nanomaterial-based sequential therapy to enhance the therapeutic efficacy for cancer.

Pancreatic cancer is characterized with abundant matrix, which blocks the attack of chemotherapeutics and reduces their

\footnotetext{
${ }^{a}$ Department of Medical Imaging, Jinling Hospital, School of Medicine, Nanjing University, Nanjing 210002, P. R. China.E-mail: tangyuxia5@163.com; tzg@fudan. edu.cn; cjr.luguangming@vip.163.com

${ }^{b}$ State Key Laboratory of Analytical Chemistry for Life Science, School of Chemistry and Chemical Engineering, Nanjing University, Nanjing 210093, P. R. China

$\dagger$ Electronic supplementary information (ESI) available. See DOI: 10.1039/c9ra02180a
}

therapeutic effects against cancer cells. ${ }^{\mathbf{9}, 10}$ There is a complex relationship between extracellular matrix (ECM) and pancreatic cancer. ${ }^{11}$ The deposition of ECM exerts mechanical and biochemical effects on pancreatic cancer cells. ${ }^{12}$ ECM cannot only directly affect the biology of pancreatic cancer cells, both also result in high interstitial hydraulic pressure, thereby impairing tumor perfusion and thus leading to anti-tumor delivery drugs. ${ }^{13}$ Therapies to completely deplete the stroma remain controversial. Treatment that target and deplete stromal cells may result in a more aggressive disease, ${ }^{\mathbf{1 4 , 1 5}}$ but the treatments that target the ECM including collagens and hyaluronic acid (HA) are being intensively studied in both preclinical and clinical research. ${ }^{\mathbf{1 6 - 1 9}}$ The drugs for pancreatic cancer matrix include polyphenols, hedgehog signaling pathway inhibitors, pancreatic astrocyte activation inhibitors, anti-cytokine drugs, and matrix inhibitors. ${ }^{20-25}$ However, these drugs are poorly water-soluble, unstable, or even high-risk for tumor metastasis. ${ }^{{ }^{20-22,24,25}}$ Recently, it is reported that losartan can inhibit type I collagen and hyaluronic acid of pancreatic cancer matrix, which is safe, inexpensive, and does not increase the risk of tumor metastasis. ${ }^{26,27}$

Mesoporous materials have been widely used for drug delivery because of their high specific surface area, large pore volume, uniform pore size, excellent biocompatibility, and high drug loading content. ${ }^{28-30}$ Herein, we constructed a core-shell structured $\mathrm{Fe}_{3} \mathrm{O}_{4}$ embedded periodic mesoporous organosilica 
spheres to load losartan $\left(\mathrm{Fe}_{3} \mathrm{O}_{4} @ \mathrm{PMO}-\mathrm{NH}_{2}\right.$-Los) for depletion of pancreatic tumor matrix. The $\mathrm{Fe}_{3} \mathrm{O}_{4} @ P M O-\mathrm{NH}_{2}$-Los effectively inhibits tumor stromal matrix, which is benefit for subsequent chemotherapy. Then gemcitabine was delivered by magnetic mesoporous silica nanocarrier $\left(\mathrm{Fe}_{3} \mathrm{O}_{4} @ \mathrm{PMO}-\mathrm{Gem}\right)$ for chemotherapy of pancreatic cancer. In vitro experiments demonstrate that the $\mathrm{Fe}_{3} \mathrm{O}_{4} @ P M O-G e m$ has a good killing ability for DSL/6A cells. In vivo anti-tumor effect shows that the sequential therapy using the $\mathrm{Fe}_{3} \mathrm{O}_{4} @ P M O-\mathrm{NH}_{2}$-Los and $\mathrm{Fe}_{3} \mathrm{O}_{4} @ P M O-G e m$ has the best therapeutic efficacy compared to monotherapy. Furthermore, T2-weighted magnetic resonance imaging (MRI) shows that the signal intensity of tumor changes after injection of the $\mathrm{Fe}_{3} \mathrm{O}_{4} @ \mathrm{PMO}-\mathrm{NH}_{2}$-Los and the tumor volumes decrease after receiving the sequential therapy.

\section{Materials and methods}

\subsection{Materials}

Bis(trimethoxysilyl)ethane (BTSE), tetraethyl orthosilicate (TEOS), aminopropyltriethoxysilane (APTES), losartan potassium, gemcitabine, Waymouth's MB 752/1 medium were purchased from Sigma-Aldrich (St. Louis, MO, USA). The grade of losartan potassium was analytical standard and the impurities were $\leq 0.5 \%$ water. Cetyltrimethyl ammonium bromide (CTAB), concentrated ammonia aqueous solution (25 wt\%), hydrochloric acid ( $\mathrm{HCl}, \mathrm{wt} 37 \%)$, and anhydrous ethanol were purchased from Sinopharm Chemical Reagent Co. Ltd. (Shanghai, China). DSL/6A (rat pancreatic ductal cancer cell line) was purchased from American Type Culture Collection (ATCC, USA). Phosphate buffered saline (PBS) and 3-(4,5dimethylthiazol-2-yl)-2,5-diphenyltetrazolium bromide (MTT) were purchased from Nanjing Keygen Biotech. Co., Ltd. (Nanjing, China). Fetal bovine serum (FBS), dimethyl sulfoxide (DMSO), and penicillin-streptomycin solution was purchased from Gibco Laboratories (Invitrogen Co, Grand Island, NY, USA). Ultrapure water (resistivity $18.2 \mathrm{M} \Omega \mathrm{cm}$ at $25{ }^{\circ} \mathrm{C}$ ) was obtained from a Milli-Q system. All chemicals were analytical grade and used as received without further treatment.

\subsection{Preparation}

$\mathrm{Fe}_{3} \mathrm{O}_{4}$ was synthesized according to our previously reported method. ${ }^{31}$ Briefly, $3.25 \mathrm{~g}$ of $\mathrm{FeCl}_{3} \cdot 6 \mathrm{H}_{2} \mathrm{O}, 1.3 \mathrm{~g}$ of trisodium citrate, $6.0 \mathrm{~g}$ of sodium acetate and $2 \mathrm{~mL}$ of $\mathrm{H}_{2} \mathrm{O}$ were in order added to $100 \mathrm{~mL}$ of ethylene glycol and stirred vigorously for $1 \mathrm{~h}$. The solution was then transferred to $250 \mathrm{~mL}$ Teflon-lined stainless-steel autoclave heating to $200{ }^{\circ} \mathrm{C}$ for $10 \mathrm{~h}$. The product was collected by a magnet and washed with water thoroughly. To prepare the $\mathrm{Fe}_{3} \mathrm{O}_{4} @ P M O, 0.04 \mathrm{~g}$ of $\mathrm{CTAB}$ was dissolved in a solution containing $65 \mathrm{~mL}$ of ethanol, $15 \mathrm{~mL}$ of $\mathrm{H}_{2} \mathrm{O}$, and concentrated ammonia aqueous solution $(0.5 \mathrm{~mL}$, $25 \mathrm{wt} \%)$. Then, $0.3 \mathrm{~mL}$ of $\mathrm{Fe}_{3} \mathrm{O}_{4}$ dispersed in $\mathrm{H}_{2} \mathrm{O}\left(13 \mathrm{mg} \mathrm{mL}^{-1}\right)$ was added and heated to $35^{\circ} \mathrm{C}$. After $1 \mathrm{~h}$, BTSE $(0.2 \mathrm{~mL})$ and TEOS $(1 \mathrm{~mL})$ were added under vigorous stirring. The reaction mixture was stirring at $35^{\circ} \mathrm{C}$ for $48 \mathrm{~h}$ to obtain $\mathrm{Fe}_{3} \mathrm{O}_{4} @ P M O$. To synthesize amino functionalized $\mathrm{Fe}_{3} \mathrm{O}_{4} @ P M O\left(\mathrm{Fe}_{3} \mathrm{O}_{4} @ P M O-\right.$ $\mathrm{NH}_{2}$ ), the $\mathrm{Fe}_{3} \mathrm{O}_{4} @ P M O$ was first prepared and $0.1 \mathrm{~mL}$ of APTES was added to the reaction solution and stirred at $35{ }^{\circ} \mathrm{C}$ for further $12 \mathrm{~h}$. The product was collected by centrifugation at 7500 RCF for $10 \mathrm{~min}$ and washed three times with ethanol. The as-synthesized products were extracted three times in ethanol $(200 \mu \mathrm{L})$ at $60{ }^{\circ} \mathrm{C}$ for $3 \mathrm{~h}$ to remove the CTAB surfactant and washed with ethanol five times and collected by centrifugation at $7500 \mathrm{RCF}$ for $10 \mathrm{~min}$ and dried under high vacuum.

\subsection{Loading and release of losartan potassium and gemcitabine}

To load losartan, $1 \mathrm{mg}$ of losartan potassium and $1 \mathrm{mg}$ of $\mathrm{Fe}_{3}$ $\mathrm{O}_{4}$ @PMO- $\mathrm{NH}_{2}$ was mixed in $1 \mathrm{~mL}$ of PBS. The mixture was stirred for $24 \mathrm{~h}$ in dark. To load gemcitabine, $1 \mathrm{mg}$ of gemcitabine was mixed with $1 \mathrm{mg}$ of $\mathrm{Fe}_{3} \mathrm{O}_{4} @ P M O$ in $1 \mathrm{~mL}$ of PBS. After stirring for $24 \mathrm{~h}$ in dark, the products were collected and washed with PBS three times to remove the unloaded drugs. The supernatant was collected and the UV-vis absorbance values at $206 \mathrm{~nm}$ and $268 \mathrm{~nm}$ are measured respectively to determine the loading contents of losartan or gemcitabine. The contents of drugs loaded in the nanoparticles were calculated by subtracting the mass of drugs remained in the supernatant from the total drugs added into the system. The drugs loading capacity was calculated by following equation: loading capacity $(\mathrm{w} / \mathrm{w})=$ $M_{\text {drug }} / M_{\text {(nanocarrier + drug) }} \times 100 \%$. Where $M_{\text {drug }}$ and $M_{\text {(nanocarrier + }}$ drug) are the mass of drugs loaded in the nanocomposites and the total mass of nanocomposites and loading drugs. For the drug release experiments, $1 \mathrm{mg} \mathrm{mL} \mathrm{m}^{-1}$ losartan or gemcitabine equivalent was suspended in PBS with $\mathrm{pH} 7.4$ or 5.0. At different time interval, it was centrifuged at $7500 \mathrm{RCF}$ for $10 \mathrm{~min}$ to collect the supernatant and then resuspend in $1 \mathrm{~mL}$ of fresh PBS. The supernatant was measured by UV-vis to calculate the amount of released drugs.

\subsection{Characterization of nanocomposites}

Transmission electron microscopy (TEM) images were obtained using a JEM-200CX transmission electron microscope (Hitachi, Tokyo, Japan). UV-vis spectrum was determined using a Lambda 35 UV-vis spectrophotometer (PerkinElmer Instruments, USA). Fourier transform-infrared (FT-IR) spectra were measured using a Nexus 870 FT-IR Spectrophotometer (USA). Zeta potential and dynamic light scattering (DLS) were recorded using a Brookhaven ZetaPlus zeta potential analyzer (Brookhaven Instruments, USA).

\subsection{Cell viability experiments}

The biocompatibility of $\mathrm{Fe}_{3} \mathrm{O}_{4} @ \mathrm{PMO}$ and $\mathrm{Fe}_{3} \mathrm{O}_{4}$ @PMO- $\mathrm{NH}_{2}$ against DSL/6A cells was measured by MTT assay. Pancreatic cancer DSL/6A cells were planted in 96-well plates at a density of 5 $\times 10^{3}$ /well and incubated in $5 \% \mathrm{CO}_{2}$ incubator (Thermo Scientific, USA) at $37{ }^{\circ} \mathrm{C}$ for $24 \mathrm{~h}$. The $\mathrm{Fe}_{3} \mathrm{O}_{4}$ @PMO and $\mathrm{Fe}_{3} \mathrm{O}_{4} @ \mathrm{PMO}-$ $\mathrm{NH}_{2}$ were added into cells, respectively, at the concentrations of 0 to $100 \mu \mathrm{g} \mathrm{mL} \mathrm{m}^{-1}$. After incubation for 24 and $48 \mathrm{~h}, 20 \mu \mathrm{L}$ of MTT $\left(5 \mathrm{mg} \mathrm{mL} \mathrm{m}^{-1}\right)$ was added and incubated for another $4 \mathrm{~h}$. Then the cells were washed by PBS twice and replaced by $100 \mu \mathrm{L}$ of dimethyl sulfoxide (DMSO). Finally, the absorbance was measured by a microplate reader (Thermo Scientific, USA) at 
$570 \mathrm{~nm}$. The DSL/6A cells treated with medium were set as control. Cell viability $(\%)=A_{\text {sample }} / A_{\text {control }} \times 100\left(A_{\text {sample }}\right.$ and $A_{\text {control }}$ represented the absorbance of treated and control cells, respectively). For the toxicity of $\mathrm{Fe}_{3} \mathrm{O}_{4} @ \mathrm{PMO} \mathrm{NH}_{2}$-Los, the same procedures were performed following the steps above except that cells were treated with $\mathrm{Fe}_{3} \mathrm{O}_{4} @ \mathrm{PMO}-\mathrm{NH}_{2}$-Los with the losartan concentrations of $0-10 \mathrm{mg} \mathrm{mL}^{-1}$ for $24 \mathrm{~h}$ and $48 \mathrm{~h}$. For evaluating therapeutic efficacy of Gem and $\mathrm{Fe}_{3} \mathrm{O}_{4} @ P M O-G e m$, the same procedures were performed following the steps above except that cells were treated with free Gem and $\mathrm{Fe}_{3} \mathrm{O}_{4} @ \mathrm{PMO}-\mathrm{Gem}$ with the Gem concentrations of 0-100 $\mu \mathrm{M}$.

\subsection{In vivo anti-tumor efficacy}

All animal procedures were performed in accordance with the Guidelines for Care and Use of Laboratory Animals of Nanjing University and experiments were approved by the Animal Ethics Committee of Jinling hospital, Jiangsu, China. The animals employed were male. The tumor bearing mice model was established by the method described previous. ${ }^{32}$ Briefly, $10^{7}$ DSL/6A cells were subcutaneous injected to the right front of $\mathrm{Balb} / \mathrm{c}$ mice (8 weeks old). When tumor reached to about 50 $\mathrm{mm}^{3}$, the mice was randomly divided into saline (group 1), $\mathrm{Fe}_{3} \mathrm{O}_{4} @ \mathrm{PMO}-\mathrm{Gem}$ (group 2), $\mathrm{Fe}_{3} \mathrm{O}_{4} @ \mathrm{PMO}-\mathrm{NH}_{2}$-Los (group 3), and $\mathrm{Fe}_{3} \mathrm{O}_{4} @ \mathrm{PMO}-\mathrm{Gem}+\mathrm{Fe}_{3} \mathrm{O}_{4} @ \mathrm{PMO}-\mathrm{NH}_{2}$-Los groups (group 4) $(n=6)$. All agents were injected via tail vein. During the first week, group 1 and 2 were injected with saline, and group 3 and 4 were injected with the $\mathrm{Fe}_{3} \mathrm{O}_{4} @ \mathrm{PMO}-\mathrm{NH}_{2}$-Los daily. Then $\mathrm{Fe}_{3}$ $\mathrm{O}_{4}$ @PMO-Gem was injected in group 2 and 4 on the 7th, 10th and 14th day, respectively. Accordingly, saline was injected in group 1 and 3. The dose of losartan and gemcitabine daily was $40 \mathrm{mg} \mathrm{kg}^{-1}$ and $10 \mathrm{mg} \mathrm{kg}^{-1}$, respectively. $\mathrm{Fe}_{3} \mathrm{O}_{4} @ \mathrm{PMO}-\mathrm{NH}_{2}$-Los and $\mathrm{Fe}_{3} \mathrm{O}_{4} @ P M O-G e m$ were suspended in saline and the injection volume was $100 \mu \mathrm{L}$. The weight of mice was monitored every other day. The tumor volumes were calculated by measuring the longest $(L)$ and shortest dimension $(S)$ using the formula: $V=\left(L \times S^{2}\right) / 2$. MRI was performed in all mice pre and post the treatment of $\mathrm{Fe}_{3} \mathrm{O}_{4} @ P M O-\mathrm{NH}_{2}$-Los. After treatment, the mice were sacrificed and the tumor was collected and weighted. Then organs including heart, liver, spleen, lung and kidney were collected. Tumor tissues and major organs were fixed by paraformaldehyde for follow-up pathological and immunohistochemical analysis. Organs were dehydrated and sliced for hematoxylin and eosin (H\&E) staining. Tumor tissues were dehydrated and sliced for H\&E staining, Masson's trichrome staining assay of type I collagen and immunohistological chemistry staining of CD31, HA, transforming growth factor- $\beta 1$ (TGF- $\beta 1$ ), connective tissue growth factor (CTGF), terminal deoxynucleotidyl transferase dUTP nick end labeling (TUNEL) and Ki67. Three tissue sections were made for each tumor, and five sections of each tissue section were observed under a 40-fold magnification microscope.
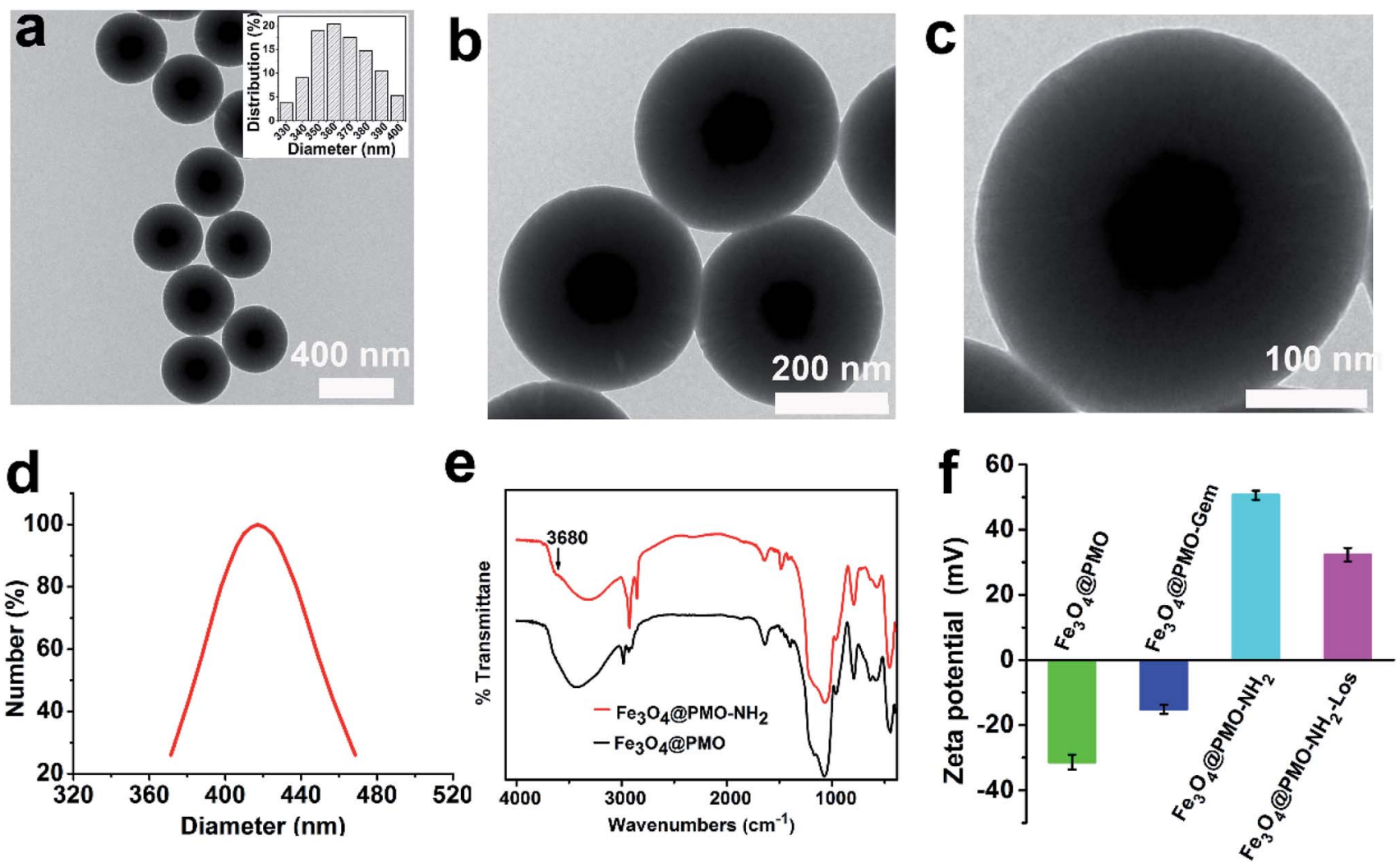

Fig. $1(\mathrm{a}-\mathrm{c})$ TEM images of the $\mathrm{Fe}_{3} \mathrm{O}_{4}$ (aPMO nanospheres at different magnifications. Inset in (a) is the size distribution of the $\mathrm{Fe}_{3} \mathrm{O}_{4} @ \mathrm{aPMO}$ by measuring 50 particles on TEM images. (d) Hydrodynamic diameter of the $\mathrm{Fe}_{3} \mathrm{O}_{4}$ (aPMO nanospheres in water. (e) FT-IR spectra of the Fe ${ }_{3}-$ $\mathrm{O}_{4} \mathrm{aPMO}$ and $\mathrm{Fe}_{3} \mathrm{O}_{4} \mathrm{QPMO}-\mathrm{NH}_{2}$. (f) Zeta potentials of the $\mathrm{Fe}_{3} \mathrm{O}_{4} @ \mathrm{aPMO}, \mathrm{Fe}_{3} \mathrm{O}_{4} @ \mathrm{aPMO}-\mathrm{Gem}_{1} \mathrm{Fe}_{3} \mathrm{O}_{4} @ \mathrm{aPMO}-\mathrm{NH}_{2}$, and Fe $\mathrm{O}_{4} @ \mathrm{aPMO}-\mathrm{NH}_{2}-\mathrm{Los}$. All experiments repeated three times. 
MRI studies were performed in a 3.0 T GE Discovery MR750, by using a $\mathrm{T} 2 *$ sequence $(\mathrm{TR}=54.2 \mathrm{~ms}, \mathrm{TE}=2.2,5.2,8.1,11.1$, $14,17,20,22.9,25.9,28.8,31.8,34.8$, and $37.7 \mathrm{~ms}$; flip angle = $25 \mathrm{deg}$; field of view $(\mathrm{FOV})=120 \mathrm{~mm}$; slice thickness $=2.5 \mathrm{~mm}$; and image size $=128 \times 128$ ). The obtained materials were dissolved in $2 \mathrm{~mL}$ of water with five different concentrations. The corresponding iron concentrations were determined by inductively coupled plasma (ICP) using a PerkinElmer Optima5300DV spectrometer (Waltham, Massachusetts, USA). Then $r_{2}$ values were calculated using a GE AW Volume share 5 programs (GE Healthcare/Greater China, Beijing, China) based on MR images.

\section{Results and discussion}

TEM images show that the obtained $\mathrm{Fe}_{3} \mathrm{O}_{4} @ P M O$ nanoparticles have a spherical shape with a mean size of $365 \mathrm{~nm}$ (Fig. 1a and b). High-magnification TEM images show the $\mathrm{Fe}_{3} \mathrm{O}_{4} @ P M O$ nanospheres have a black core encapsulated with a grey periodic organosilica shell (Fig. 1c). The diameter of the $\mathrm{Fe}_{3} \mathrm{O}_{4}$ core is measured to be approximately $100 \mathrm{~nm}$. DLS analysis reveal that hydrodynamic particle size of the $\mathrm{Fe}_{3} \mathrm{O}_{4} @ \mathrm{PMO}$ nanospheres is $428 \mathrm{~nm}$, suggesting that the $\mathrm{Fe}_{3} \mathrm{O}_{4} @ P M O$ has a good dispersity in water (Fig. 1d). FT-IR spectrum of the $\mathrm{Fe}_{3} \mathrm{O}_{4} @ P M O$ shows characteristic Si-O bands at $900-1300 \mathrm{~cm}^{-1}$ and $\mathrm{C}-\mathrm{H}$ bonds at 1414 and $2900 \mathrm{~cm}^{-1}$, demonstrating the successful coating of ethane-bridged organosilica frameworks. The zeta potential of the $\mathrm{Fe}_{3} \mathrm{O}_{4} @ \mathrm{PMO}$ is $-31.4 \mathrm{mV}$, which can be used to load positively charged gemcitabine via electrostatic interaction. The surface charge changes to $-\mathbf{1 5 . 2} \mathrm{mV}$ after loaded with gemcitabine, suggesting the successfully loading of gemcitabine. FT-IR spectrum of the $\mathrm{Fe}_{3} \mathrm{O}_{4} @ \mathrm{PMO}-\mathrm{NH}_{2}$ shows the band of $\mathrm{N}-\mathrm{H}$ bond stretching of aminopropyl groups at $3680 \mathrm{~cm}^{-1}$, suggesting that $\mathrm{NH}_{2}$ was successfully modified on $\mathrm{Fe}_{3} \mathrm{O}_{4} @ \mathrm{PMO}$ particles (Fig. 1e). The zeta potential of the $\mathrm{Fe}_{3} \mathrm{O}_{4} @ \mathrm{PMO}-\mathrm{NH}_{2}$ is measure to be as high as $+50.6 \mathrm{mV}$. After loading negatively charged losartan, the zeta potential of the $\mathrm{Fe}_{3} \mathrm{O}_{4} @ \mathrm{PMO}-\mathrm{NH}_{2}$ decreased to $+32.3 \mathrm{mV}$, indicating successful loading of losartan (Fig. 1f). The loading content for gemcitabine and losartan is calculated up to $27.2 \%$ and $32.7 \%$, respectively. We have studied the release profiles of drugs from particles at different $\mathrm{pH}$ conditions and found that more drugs released at $\mathrm{pH} 5.0$ (Fig. $\mathrm{S} 1 \dagger$ ). At acidic condition, the drug can be release via ion exchange mechanism with $\mathrm{H}^{+}$(Fig. $\mathrm{S} 1 \dagger$ ).

The biocompatibility of the prepared $\mathrm{Fe}_{3} \mathrm{O}_{4} @ \mathrm{PMO}, \mathrm{Fe}_{3^{-}}$ $\mathrm{O}_{4} @ \mathrm{PMO}-\mathrm{NH}_{2}$ was evaluated by assessing their effect on cell proliferation. The results show that the viability of DSL/6A pancreatic cancer cells are higher than $80 \%$ when incubated with the materials for $24 \mathrm{~h}$ (Fig. 2a). With prolonging incubation time to $48 \mathrm{~h}$, the cell viability is still higher than $75 \%$ at the materials' concentration of $100 \mu \mathrm{g} \mathrm{mL}{ }^{-1}$ (Fig. 2b). The same results were observed when DSL/6A pancreatic cancer cells were incubated with $\mathrm{Fe}_{3} \mathrm{O}_{4} @ \mathrm{PMO}-\mathrm{NH}_{2}$-Los for $24 \mathrm{~h}$ and $48 \mathrm{~h}$. (Fig. S2 $\dagger$ ) These results indicate the $\mathrm{Fe}_{3} \mathrm{O}_{4} @ \mathrm{PMO}, \mathrm{Fe}_{3} \mathrm{O}_{4} @ \mathrm{PMO}-$
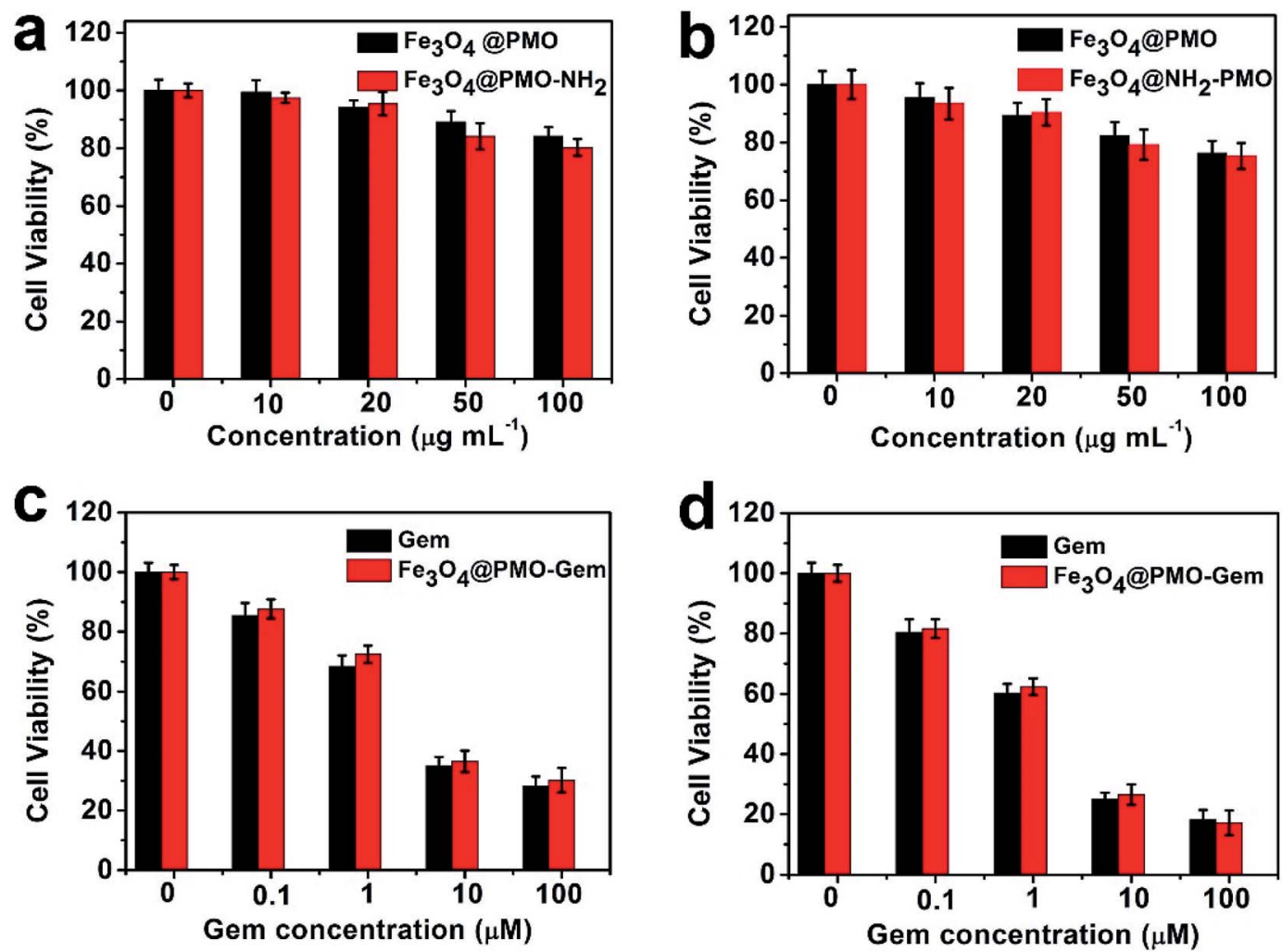

Fig. 2 In vitro viability of pancreatic cancer DSL/6A cells incubated with $\mathrm{Fe}_{3} \mathrm{O}_{4} @ \mathrm{aPMO}$ and $\mathrm{Fe}_{3} \mathrm{O}_{4} @ \mathrm{aPMO}-\mathrm{NH}_{2}$ for (a) $24 \mathrm{~h}$ and (b) $48 \mathrm{~h}$. Viability of $\mathrm{DSL} / 6 \mathrm{~A}$ cells incubated with different concentrations of free gemcitabine and $\mathrm{Fe}_{3} \mathrm{O}_{4} \mathrm{QPMO}-\mathrm{Gem}$ for (c) $24 \mathrm{~h}$ and (d) $48 \mathrm{~h}$. Each group has 5 repeat wells. 
a

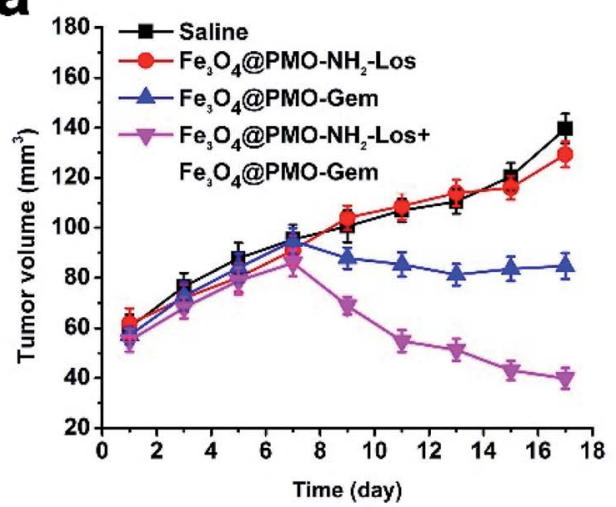

C

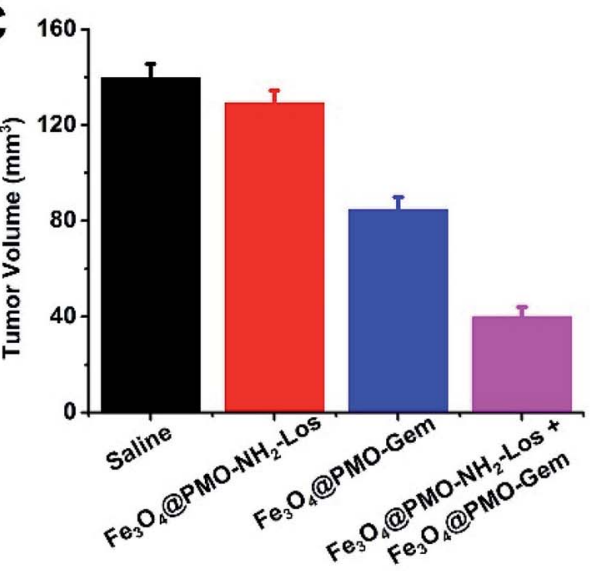

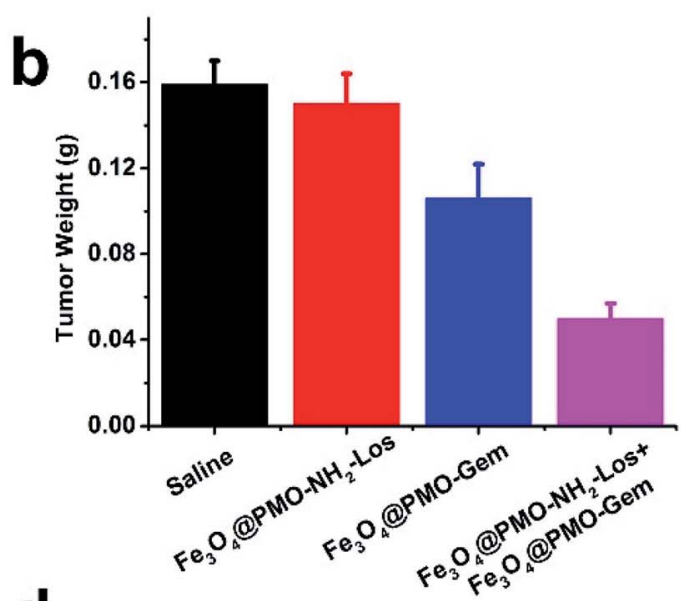

d

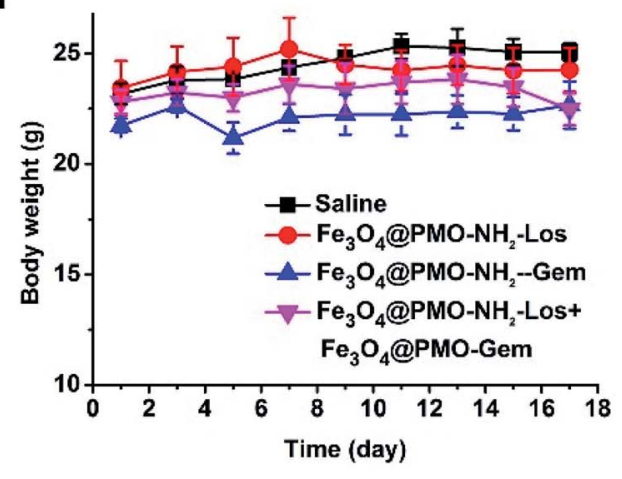

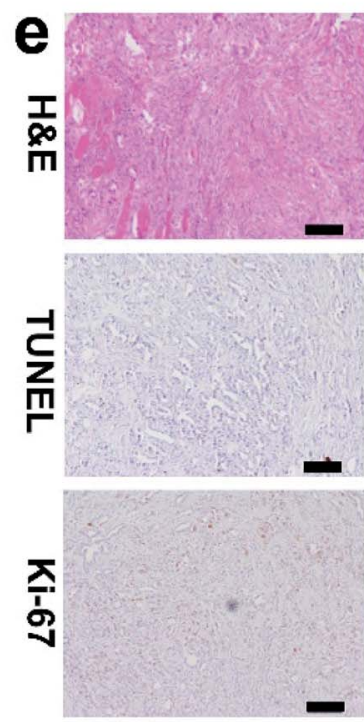
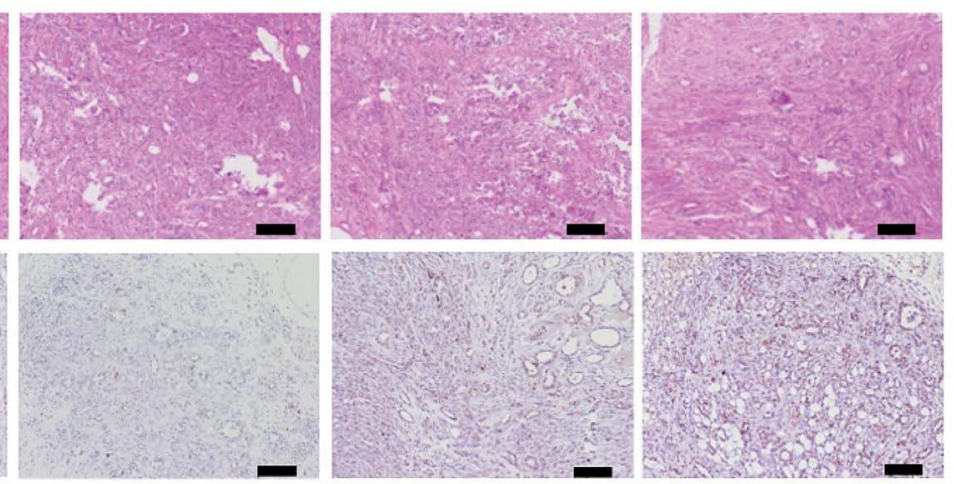

saline<smiles>O[Mg]O[Mg]O[Mg]</smiles><smiles>O[Co]</smiles><smiles>[GeH2]=[W]</smiles>

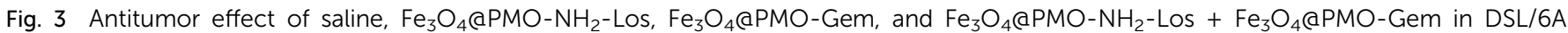
xenograft bearing mice $(n=6)$. (a) Tumor volume of the mice treated with different treatments. All agents were intravenously injected. During the first week, saline, or $\mathrm{Fe}_{3} \mathrm{O}_{4}$ aPMO- $\mathrm{NH}_{2}$-Los was injected daily. Then saline or Fe $\mathrm{O}_{4}$ (aPMO-Gem was injected on the 7th, 10th and 14th day. (b) Tumor weight, (c) volume and (d) body weight change profiles after treatment. (e) H\&E, TUNEL and Ki-67 staining of tumor slices in different groups. Three tissue sections were made for each tumor, and five sections of each tissue section were observed under a 40 -fold magnification microscope. Scale bar: $20 \mu \mathrm{m}$. 
$\mathrm{NH}_{2}$ and $\mathrm{Fe}_{3} \mathrm{O}_{4} @ \mathrm{PMO} \mathrm{NH}_{2}$-Los have good biocompatibility, allowing them to be further used to deliver gemcitabine and losartan. Then we investigated the killing ability of $\mathrm{Fe}_{3} \mathrm{O}_{4}$ @PMO-Gem on DSL/6A cells. The $\mathrm{Fe}_{3} \mathrm{O}_{4} @ P M O-G e m$ show similar killing effect compared to free gemcitabine at the drug concentrations of $0.1-100 \mu \mathrm{M}$ and the cells variability decreases to $30 \%$ when incubated with $100 \mu \mathrm{M}$ of $\mathrm{Fe}_{3} \mathrm{O}_{4} @$ @POO-Gem for $24 \mathrm{~h}$ (Fig. 2c). When the incubation time prolonged to $48 \mathrm{~h}$, the cell survival rate decreases to $18 \%$ at the $\mathrm{Fe}_{3} \mathrm{O}_{4} @$ @PMO-Gem concentration of $100 \mu \mathrm{M}$ (Fig. 2d). These results demonstrate that $\mathrm{Fe}_{3} \mathrm{O}_{4} @$ PMO-Gem has strong killing ability for the pancreatic cancer DSL/6A cells.

Next, we studied the in vivo sequential therapeutic efficacy of the $\mathrm{Fe}_{3} \mathrm{O}_{4} @ P M O-\mathrm{NH}_{2}$-Los and $\mathrm{Fe}_{3} \mathrm{O}_{4} @ P M O-G e m$ on DSL/6A tumor bearing mice. Four groups of mice were intravenously injected with saline, $\mathrm{Fe}_{3} \mathrm{O}_{4} @ P M O-\mathrm{NH}_{2}$-Los, $\mathrm{Fe}_{3} \mathrm{O}_{4} @ P M O-G e m$, and $\mathrm{Fe}_{3} \mathrm{O}_{4} @ \mathrm{PMO}-\mathrm{NH}_{2}$-Los $+\mathrm{Fe}_{3} \mathrm{O}_{4} @ P M O-G e m$ (sequential therapy). The results show that the tumor volume increases rapidly in saline group (Fig. 3a). Tumors treated with $\mathrm{Fe}_{3} \mathrm{O}_{4}$ @PMO- $\mathrm{NH}_{2}$-Los have the same trend as the saline group, indicating that losartan had no direct effect on tumor growth. When $\mathrm{Fe}_{3} \mathrm{O}_{4} @ P M O-G e m$ was injected on the 8th day, tumor growth is inhibited and the tumor growth becomes slowly. Notably, the tumor volume decreases most in the $\mathrm{Fe}_{3} \mathrm{O}_{4} @ \mathrm{PMO}-\mathrm{NH}_{2}$-Los + $\mathrm{Fe}_{3} \mathrm{O}_{4} @ P M O-G e m$ group, indicating the sequential therapy has the best therapeutic efficacy. At the end of the treatment, the volume and weights of the tumors were measured (Fig. $3 \mathrm{~b}$ and c). The tumor volume of the mice treated with saline, $\mathrm{Fe}_{3} \mathrm{O}_{4}$ @PMO- $\mathrm{NH}_{2}$-Los, $\mathrm{Fe}_{3} \mathrm{O}_{4} @ P M O-G e m$, and $\mathrm{Fe}_{3} \mathrm{O}_{4} @ P M O-\mathrm{NH}_{2}$-Los + $\mathrm{Fe}_{3} \mathrm{O}_{4} @$ @PMO-Gem group is $139.6 \pm 6.0,129.3 \pm 5.1,84.7 \pm 5.2$ and $39.9 \pm 4.2 \mathrm{~mm}^{3}$, respectively. Comparing with saline group, the tumor volume treated with $\mathrm{Fe}_{3} \mathrm{O}_{4} @ P M O-\mathrm{NH}_{2}$-Los, $\mathrm{Fe}_{3}$ $\mathrm{O}_{4} @ P M O-G e m$, and $\mathrm{Fe}_{3} \mathrm{O}_{4} @ P M O-\mathrm{NH}_{2}$-Los $+\mathrm{Fe}_{3} \mathrm{O}_{4} @ P M O-G e m$ decrease to $92.6 \%, 60.7 \%$, and $28.6 \%$, respectively. The tumor weight for the mice treated with saline, $\mathrm{Fe}_{3} \mathrm{O}_{4} @ \mathrm{PMO}^{-\mathrm{NH}_{2}}$-Los, $\mathrm{Fe}_{3} \mathrm{O}_{4} @ P M O-G e m$ and $\mathrm{Fe}_{3} \mathrm{O}_{4} @ P M O-\mathrm{NH}_{2}-\mathrm{Los}+\mathrm{Fe}_{3} \mathrm{O}_{4} @ P M O-$ Gem treatment is $0.16 \pm 0.01,0.15 \pm 0.01,0.11 \pm 0.02,0.05 \pm$ $0.01 \mathrm{~g}$, respectively, further confirmed the sequential therapy has the best therapeutic efficacy for pancreatic tumor. No obvious body weight changes are observed in different mouse groups (Fig. 3d), indicating no significant toxicity of these therapeutic agents. H\&E and TUNEL staining demonstrate that there are increased necrosis and apoptosis after the treatment of $\mathrm{Fe}_{3} \mathrm{O}_{4} @$ @PMO-Gem and $\mathrm{Fe}_{3} \mathrm{O}_{4}$ @PMO-Gem $+\mathrm{Fe}_{3} \mathrm{O}_{4} @ P M O-$ $\mathrm{NH}_{2}$-Los (Fig. 3e). The expression level of cell proliferation factor ki67 is very high in the saline and $\mathrm{Fe}_{3} \mathrm{O}_{4} @ \mathrm{PMO}^{-\mathrm{NH}_{2}}$-Los

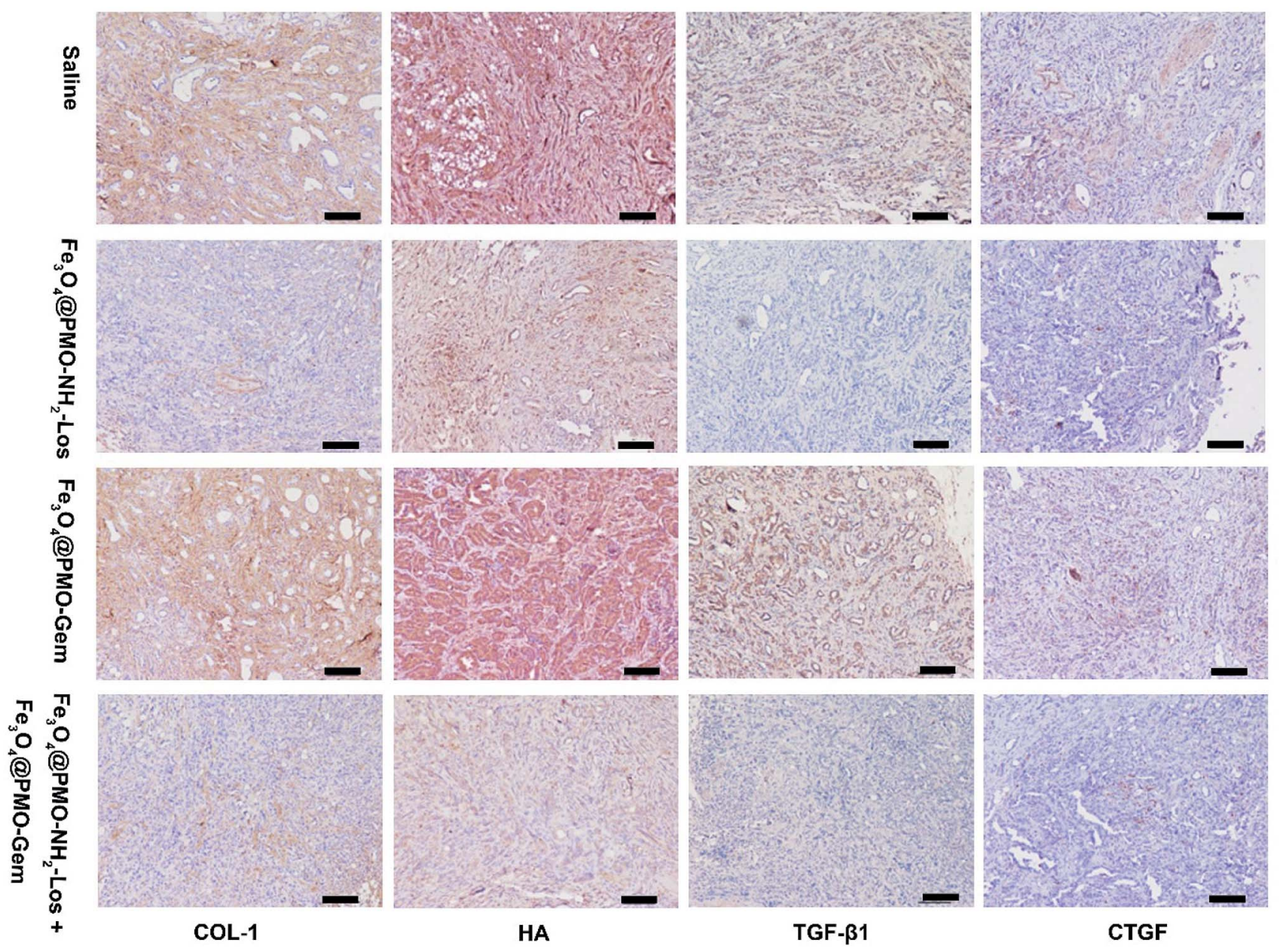

Fig. 4 Representative images of immunohistochemistry staining of COL-1, HA, TGF- $\beta 1$ and CTGF of DSL/6A tumor from different groups after different treatments. 


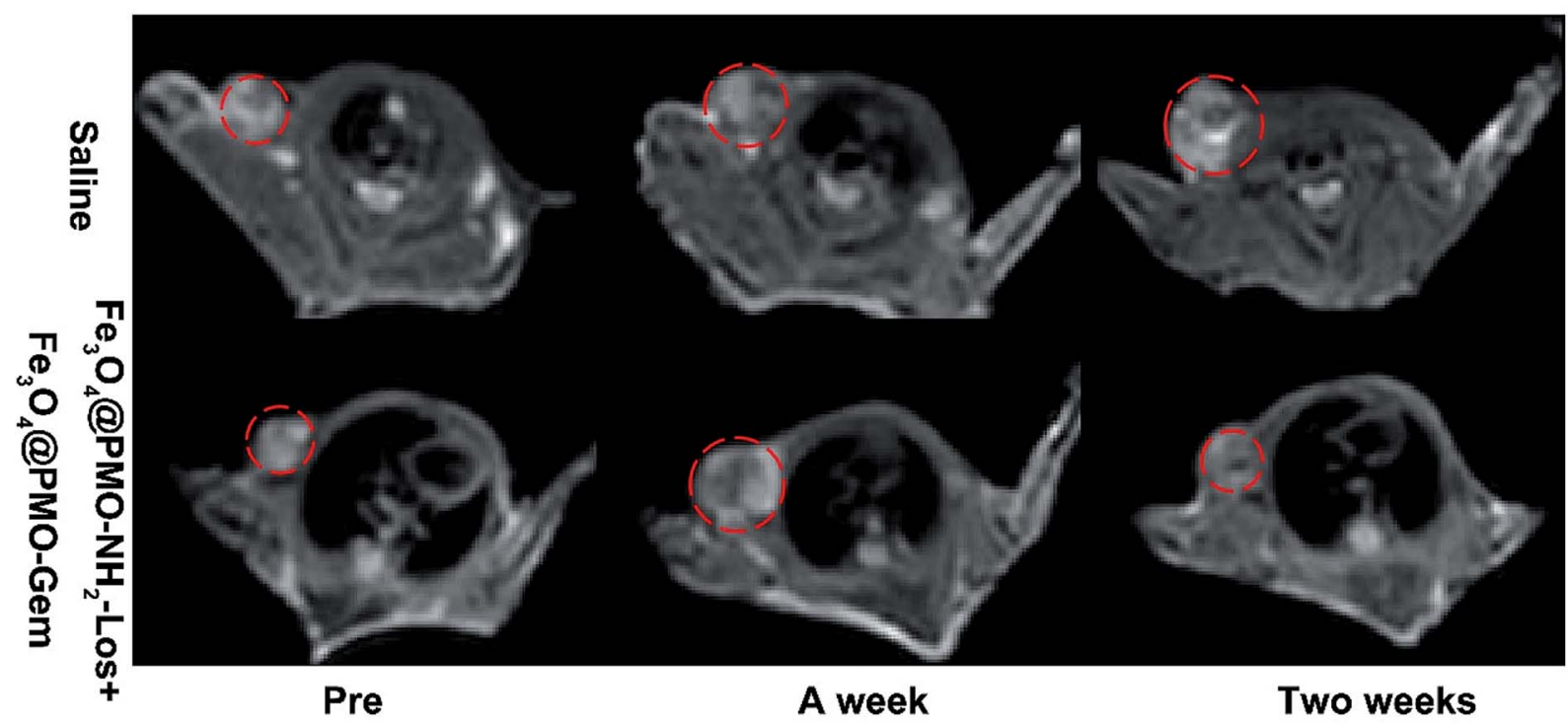

Fig. 5 T2-weighted MR imaging of pancreatic tumor DSL/6A-bearing mice at different time points pre and post injection of Fe $\mathrm{O}_{4}\left(\mathrm{aPMO}-\mathrm{NH}_{2}-\right.$ Los and $\mathrm{Fe}_{3} \mathrm{O}_{4}$ (aPMO-Gem $(n=6)$. The dotted circles indicate the DSL/6A pancreatic tumors.

group. In contrast, ki67 is obviously reduced in the $\mathrm{Fe}_{3} \mathrm{O}_{4}$ @PMO-Gem and $\mathrm{Fe}_{3} \mathrm{O}_{4} @ P M O-G e m+\mathrm{Fe}_{3} \mathrm{O}_{4} @ P M O-\mathrm{NH}_{2}$-Los group, demonstrating inhibition for tumor proliferation. The in vivo toxicity is further measured using H\&E staining of organs at the end of the treatment (Fig. S3†). There are no obvious changes, such as degeneration, necrosis, steatosis, inflammatory cell infiltration in the myocardial, liver, spleen, lung and kidney, demonstrating that whether using $\mathrm{Fe}_{3} \mathrm{O}_{4} @ \mathrm{PMO}^{-} \mathrm{NH}_{2}-$ Los, $\mathrm{Fe}_{3} \mathrm{O}_{4} @$ PMO-Gem alone, or sequential therapy combing them together have no obvious toxicity to the major organs of mice.

Because the sequential therapy using $\mathrm{Fe}_{3} \mathrm{O}_{4} @ \mathrm{PMO}-\mathrm{NH}_{2}$-Los $+\mathrm{Fe}_{3} \mathrm{O}_{4} @$ @PMO-Gem has the best anti-tumor effect, we further explore the mechanisms by immunohistochemistry of the tumor tissues (Fig. 4). Considering type I collagen and HA are the main constituents of the extracellular matrix of tumor, we investigated the changes of these components. The results show that type I collagen and $\mathrm{HA}$ in tumor tissues are significantly down-regulated after the treatment using $\mathrm{Fe}_{3} \mathrm{O}_{4} @ P M O-\mathrm{NH}_{2}$-Los or $\mathrm{Fe}_{3} \mathrm{O}_{4} @ \mathrm{PMO}-\mathrm{Gem}+\mathrm{Fe}_{3} \mathrm{O}_{4} @$ OPMO- $\mathrm{NH}_{2}$-Los, which facilitates the entrance of $\mathrm{Fe}_{3} \mathrm{O}_{4} @$ @PMO-Gem to kill tumor cells. Transient fibrosis of the tumor matrix is caused by the activation of TGF$\beta$ and the fixation of this fibrosis requires the synergy of CTGF. So, we further analyzed the expression of TGF- $\beta$ and CTGF. The results show that TGF- $\beta$ and CTGF are obviously downregulated after the treatment of $\mathrm{Fe}_{3} \mathrm{O}_{4} @ \mathrm{PMO}-\mathrm{NH}_{2}$-Los and $\mathrm{Fe}_{3} \mathrm{O}_{4} @ P M O-G e m+\mathrm{Fe}_{3} \mathrm{O}_{4} @ P M O-\mathrm{NH}_{2}$-Los, suggesting that $\mathrm{Fe}_{3} \mathrm{O}_{4} @ \mathrm{PMO}-\mathrm{NH}_{2}$-Los down regulates type I collagen and HA via reducing TGF- $\beta$ and CTGF. In addition, the endothelial marker CD31 after the treatment shows no significant changes, indicating that $\mathrm{Fe}_{3} \mathrm{O}_{4} @ P M O-\mathrm{NH}_{2}$-Los does not cause changes in vascular density (Fig. S4 $\dagger$ ).

Because the $\mathrm{Fe}_{3} \mathrm{O}_{4} @ \mathrm{PMO}$ and $\mathrm{Fe}_{3} \mathrm{O}_{4} @ \mathrm{PMO}-\mathrm{NH}_{2}$ contain magnetic cores, which can be used for tumor MRI. The magnetic resonance $T_{2}$-weighted images became darker as the iron concentration increases from 0 to $1.0 \mu \mathrm{M}$ (Fig. S5a $\dagger$ ). The $r_{2}^{*}$ values of both the $\mathrm{Fe}_{3} \mathrm{O}_{4} @ P M O$ and $\mathrm{Fe}_{3} \mathrm{O}_{4} @ \mathrm{PMO} \mathrm{NH}_{2}$ are calculated to be $199.7 \mathrm{mM}^{-1} \mathrm{~s}^{-1}$, suggesting that these two materials have high $r_{2}^{*}$ values and can be used for MRI to monitor the arrival of the nanodrugs in tumor sites and therapeutic effects (Fig. S5b†). The results show that the tumor turned darker on the T2 weighted images after the injection of $\mathrm{Fe}_{3} \mathrm{O}_{4} @ \mathrm{PMO}-\mathrm{NH}_{2}$-Los (Fig. 5 and S5c $\dagger$ ). These results demonstrated that $\mathrm{Fe}_{3} \mathrm{O}_{4} @ \mathrm{PMO}^{-} \mathrm{NH}_{2}$-Los can reach tumor sites. In addition, the MRI images shows that the volume of tumors is significantly smaller than that of the control group after treatment, further indicating that the sequential therapy strategy has perfect anti-tumor effect (Fig. 5).

\section{Conclusion}

In this study, sequential therapy is demonstrated using $\mathrm{Fe}_{3}$ $\mathrm{O}_{4} @ \mathrm{PMO}-\mathrm{NH}_{2}$-Los and $\mathrm{Fe}_{3} \mathrm{O}_{4} @ P M O-G e m$ to improve chemotherapy efficacy of pancreatic cancer. The loading contents of gemcitabine and losartan in the magnetic mesoporous spheres were measured up to $27.2 \%$ and $32.7 \%$, respectively. Cell viability experiments indicate that the $\mathrm{Fe}_{3} \mathrm{O}_{4} @ P M O-G e m$ has strong killing ability for pancreatic cancer cell. In vivo antitumor results show that stromal collagen and hyaluronan acid, transforming growth factor- $\beta 1$ and connective tissue growth factor can be obviously reduced by $\mathrm{Fe}_{3} \mathrm{O}_{4} @ \mathrm{PMO}^{-} \mathrm{NH}_{2}-$ Los. The pretreatment with $\mathrm{Fe}_{3} \mathrm{O}_{4} @ \mathrm{PMO}-\mathrm{NH}_{2}$-Los can significantly enhance the subsequent therapeutic efficacy of $\mathrm{Fe}_{3}$ $\mathrm{O}_{4} @ P M O-G e m$. Simultaneously, there are no obviously changes of the body weight of mice during treatment and the H\&E staining of major organs including heart, liver, spleen, lung and kidney, demonstrating that the sequential therapy has no significant toxicity to mice, showing promise for pancreatic cancer treatment. 


\section{Conflicts of interest}

The authors declare that they have no conflict of interest.

\section{Acknowledgements}

We greatly appreciate financial support from the National Key Basic Research Program of the PRC (2014CB744501 and 2014CB744504), the National Natural Science Foundation of China (81401469, 81601555, 81871420, 81601554, 81501537, and 8140070836), and the Natural Science Foundation of Jiangsu Province (BK20160017), and the National Natural Science Foundation of China (21603106).

\section{References}

1 J. L. Paris, M. V. Cabanas, M. Manzano and M. Vallet-Regi, ACS Nano, 2015, 9, 11023-11033.

2 G. Yang, L. Xu, Y. Chao, J. Xu, X. Sun, Y. Wu, R. Peng and Z. Liu, Nat. Commun., 2017, 8, 902.

3 T. Xia, M. Kovochich, M. Liong, H. Meng, S. Kabehie, S. George, J. I. Zink and A. E. Nel, ACS Nano, 2009, 3, 32733286.

4 K. J. Norsworthy, A. E. DeZern, H. L. Tsai, W. A. Hand, R. Varadhan, S. D. Gore, I. Gojo, K. Pratz, H. E. Carraway, M. Showel, M. A. McDevitt, D. Gladstone, G. Ghiaur, G. Prince, A. H. Seung, D. Benani, M. J. Levis, J. E. Karp and B. D. Smith, Leuk. Res., 2017, 61, 25-32.

5 J. M. Liou, C. C. Chen, Y. C. Lee, C. Y. Chang, J. Y. Wu, M. J. Bair, J. T. Lin, M. J. Chen, M. S. Wu, D. Taiwan Gastrointestinal and C. Helicobacter, Aliment. Pharmacol. Ther., 2016, 43, 470-481.

6 E. Calvo, M. Schmidinger, D. Y. Heng, V. Grunwald and B. Escudier, Cancer Treat. Rev., 2016, 50, 109-117.

7 W. J. Curran Jr, R. Paulus, C. J. Langer, R. Komaki, J. S. Lee, S. Hauser, B. Movsas, T. Wasserman, S. A. Rosenthal, E. Gore, M. Machtay, W. Sause and J. D. Cox, J. Natl. Cancer Inst., 2011, 103, 1452-1460.

8 Y. Wang, R. Zhao, B. Wang, Q. Zhao, Z. Li, L. Zhu-Ge, W. Yin and Y. Xie, Eur. J. Clin. Pharmacol., 2018, 74, 1-13.

9 M. Erkan, S. Hausmann, C. W. Michalski, A. A. Fingerle, M. Dobritz, J. Kleeff and H. Friess, Nat. Rev. Gastroenterol. Hepatol., 2012, 9, 454-467.

10 A. Neesse, H. Algul, D. A. Tuveson and T. M. Gress, Gut, 2015, 64, 1476-1484.

11 M. Weniger, K. C. Honselmann and A. S. Liss, The Extracellular Matrix and Pancreatic Cancer: A Complex Relationship, Cancers, 2018, 10, 316.

12 A. D. Rhim, P. E. Oberstein, D. H. Thomas, E. T. Mirek, C. F. Palermo, S. A. Sastra, E. N. Dekleva, T. Saunders, C. P. Becerra, I. W. Tattersall, C. B. Westphalen, J. Kitajewski, M. G. Fernandez-Barrena, M. E. FernandezZapico, C. Iacobuzio-Donahue, K. P. Olive and B. Z. Stanger, Cancer Cell, 2014, 25, 735-747.

13 M. A. Jacobetz, D. S. Chan, A. Neesse, T. E. Bapiro, N. Cook, K. K. Frese, C. Feig, T. Nakagawa, M. E. Caldwell, H. I. Zecchini, M. P. Lolkema, P. Jiang, A. Kultti,
C. B. Thompson, D. C. Maneval, D. I. Jodrell, G. I. Frost, H. M. Shepard, J. N. Skepper and D. A. Tuveson, Gut, 2013, 62, 112-120.

14 K. P. Olive, M. A. Jacobetz, C. J. Davidson, A. Gopinathan, D. McIntyre, D. Honess, B. Madhu, M. A. Goldgraben, M. E. Caldwell, D. Allard, K. K. Frese, G. Denicola, C. Feig, C. Combs, S. P. Winter, H. Ireland-Zecchini, S. Reichelt, W. J. Howat, A. Chang, M. Dhara, L. Wang, F. Ruckert, R. Grutzmann, C. Pilarsky, K. Izeradjene, S. R. Hingorani, P. Huang, S. E. Davies, W. Plunkett, M. Egorin, R. H. Hruban, N. Whitebread, K. McGovern, J. Adams, C. Iacobuzio-Donahue, J. Griffiths and D. A. Tuveson, Science, 2009, 324, 1457-1461.

15 B. C. Ozdemir, T. Pentcheva-Hoang, J. L. Carstens, X. Zheng, C. C. Wu, T. R. Simpson, H. Laklai, H. Sugimoto, C. Kahlert, S. V. Novitskiy, A. De Jesus-Acosta, P. Sharma, P. Heidari, U. Mahmood, L. Chin, H. L. Moses, V. M. Weaver, A. Maitra, J. P. Allison, V. S. LeBleu and R. Kalluri, Cancer Cell, 2015, 28, 831-833.

16 K. Y. Aguilera, H. Huang, W. Du, M. M. Hagopian, Z. Wang, S. Hinz, T. H. Hwang, H. Wang, J. B. Fleming, D. H. Castrillon, X. Ren, K. Ding and R. A. Brekken, Mol. Cancer Ther., 2017, 16, 2473-2485.

17 S. R. Hingorani, W. P. Harris, J. T. Beck, B. A. Berdov, S. A. Wagner, E. M. Pshevlotsky, S. A. Tjulandin, O. A. Gladkov, R. F. Holcombe, R. Korn, N. Raghunand, S. Dychter, P. Jiang, H. M. Shepard and C. E. Devoe, Clin. Cancer Res., 2016, 22, 2848-2854.

18 M. A. Jacobetz, D. S. Chan, A. Neesse, T. E. Bapiro, N. Cook, K. K. Frese, C. Feig, T. Nakagawa, M. E. Caldwell, H. I. Zecchini, M. P. Lolkema, P. Jiang, A. Kultti, C. B. Thompson, D. C. Maneval, D. I. Jodrell, G. I. Frost, H. M. Shepard, J. N. Skepper and D. A. Tuveson, Gut, 2013, 62, 112-120.

19 H. Laklai, Y. A. Miroshnikova, M. W. Pickup, E. A. Collisson, G. E. Kim, A. S. Barrett, R. C. Hill, J. N. Lakins, D. D. Schlaepfer, J. K. Mouw, V. S. LeBleu, N. Roy, S. V. Novitskiy, J. S. Johansen, V. Poli, R. Kalluri, C. A. Iacobuzio-Donahue, L. D. Wood, M. Hebrok, K. Hansen, H. L. Moses and V. M. Weaver, Nat. Med., 2016, 22, 497-505.

20 H. Meng, Y. Zhao, J. Dong, M. Xue, Y. S. Lin, Z. Ji, W. X. Mai, H. Zhang, C. H. Chang, C. J. Brinker, J. I. Zink and A. E. Nel, ACS Nano, 2013, 7, 10048-10065.

21 P. P. Provenzano, C. Cuevas, A. E. Chang, V. K. Goel, D. D. Von Hoff and S. R. Hingorani, Cancer Cell, 2012, 21, 418-429.

22 X. Li, X. Lu and H. Chen, Pancreatology, 2011, 11, 5-11.

23 N. Suzuki, A. Masamune, K. Kikuta, T. Watanabe, K. Satoh and T. Shimosegawa, Dig. Dis. Sci., 2009, 54, 802-810.

24 K. P. Olive, M. A. Jacobetz, C. J. Davidson, A. Gopinathan, D. McIntyre, D. Honess, B. Madhu, M. A. Goldgraben, M. E. Caldwell, D. Allard, K. K. Frese, G. Denicola, C. Feig, C. Combs, S. P. Winter, H. Ireland-Zecchini, S. Reichelt, W. J. Howat, A. Chang, M. Dhara, L. Wang, F. Ruckert, R. Grutzmann, C. Pilarsky, K. Izeradjene, S. R. Hingorani, P. Huang, S. E. Davies, W. Plunkett, M. Egorin, 
R. H. Hruban, N. Whitebread, K. McGovern, J. Adams, C. Iacobuzio-Donahue, J. Griffiths and D. A. Tuveson, Science, 2009, 324, 1457-1461.

25 M. Kraman, P. J. Bambrough, J. N. Arnold, E. W. Roberts, L. Magiera, J. O. Jones, A. Gopinathan, D. A. Tuveson and D. T. Fearon, Science, 2010, 330, 827-830.

26 M. C. Michel, C. Foster, H. R. Brunner and L. Liu, Pharmacol. Rev., 2013, 65, 809-848.

27 C. Hu, X. Liu, W. Ran, J. Meng, Y. Zhai, P. Zhang, Q. Yin, H. Yu, Z. Zhang and Y. Li, Biomaterials, 2017, 144, 60-72.

28 V. P. Chauhan, J. D. Martin, H. Liu, D. A. Lacorre, S. R. Jain, S. V. Kozin, T. Stylianopoulos, A. S. Mousa, X. Han,
P. Adstamongkonkul, Z. Popovic, P. Huang, M. G. Bawendi, Y. Boucher and R. K. Jain, Nat. Commun., 2013, 4, 2516.

29 P. L. Abbaraju, M. Jambhrunkar, Y. Yang, Y. Liu, Y. Lu and C. Yu, Chem. Commun., 2018, 54, 2020-2023.

30 Z. Teng, W. Li, Y. Tang, A. Elzatahry, G. Lu and D. Zhao, Adv. Mater., 2018, e1707612, DOI: 10.1002/adma.201707612.

31 Y. Tang, Y. Liu, W. Li, Y. Xie, Y. J. Li, J. Wu, S. Wang, Y. Tian, W. Tian, Z. Teng and G. Lu, RSC Adv., 2016, 6, 62550-62555. 32 Y. Tang, Z. Teng, Y. Liu, Y. Tian, J. Sun, S. Wang, C. Wang, J. Wang and G. M. Lu, J. Mater. Chem. B, 2014, 2, 4356-4362. 